\title{
Characteristics of total gaseous mercury (TGM) concentrations in an industrial complex in South Korea: impacts from local sources
}

\author{
Yong-Seok Seo ${ }^{1,2}$, Seung-Pyo Jeong ${ }^{1}$, Thomas M. Holsen ${ }^{3}$, Young-Ji Han ${ }^{4}$, Eunhwa Choi ${ }^{5}$, Eun Ha Park ${ }^{1}$, Tae \\ Young Kim ${ }^{1}$, Hee-Sang Eum ${ }^{1}$, Dae Gun Park ${ }^{1}$, Eunhye Kim ${ }^{6}$, Soontae Kim ${ }^{6}$, Jeong-Hun Kim ${ }^{7}$, Jaewon Choi ${ }^{8}$, and \\ Seung-Muk Yi ${ }^{1,2}$ \\ ${ }^{1}$ Department of Environmental Health, Graduate School of Public Health, Seoul National University, 1 Gwanak, \\ Gwanak-ro, Gwanak-gu, Seoul 151-742, South Korea \\ ${ }^{2}$ Institute of Health and Environment, Seoul National University, 1 Gwanak, Gwanak-ro, Gwanak-gu, \\ Seoul 151-742, South Korea \\ ${ }^{3}$ Department of Civil and Environmental Engineering, Clarkson University, Potsdam, NY 13699, USA \\ ${ }^{4}$ Department of Environmental Science, Kangwon National University, 192-1, Hyoja-2-dong, Chuncheon, \\ Kangwondo, 200-701, South Korea \\ ${ }^{5}$ Asian Institute for Energy, Environment \& Sustainability, Seoul National University, 1 Gwanak-ro, Gwanak-gu, \\ Seoul 151-742, South Korea \\ ${ }^{6}$ Department of Environmental, Civil and Transportation Engineering, Ajou University, Woncheon-dong, Yeongtong-gu, \\ Suwon, 443-749, South Korea \\ ${ }^{7}$ Division of Air Pollution Engineering, Department of Climate and Air Quality Research, National Institute \\ of Environmental Research, Hwangyong-ro 42, Seogu, Incheon, 404-708, South Korea \\ ${ }^{8}$ University of Pennsylvania, Philadelphia, PA 19104, USA
}

Correspondence to: Seung-Muk Yi (yiseung@ @nu.ac.kr)

Received: 18 November 2015 - Published in Atmos. Chem. Phys. Discuss.: 18 January 2016

Revised: 18 July 2016 - Accepted: 19 July 2016 - Published: 11 August 2016

\begin{abstract}
Total gaseous mercury (TGM) concentrations were measured every $5 \mathrm{~min}$ in Pohang, Gyeongsangbukdo, Korea, during summer (17-23 August 2012), fall (917 October 2012), winter (22-29 January 2013), and spring (26 March-3 April 2013) to (1) characterize the hourly and seasonal variations of atmospheric TGM concentrations; (2) identify the relationships between TGM and co-pollutants; and (3) identify likely source directions and locations of TGM using the conditional probability function (CPF), conditional bivariate probability function (CBPF) and total potential source contribution function (TPSCF).

The TGM concentration was statistically significantly highest in fall $\left(6.7 \pm 6.4 \mathrm{ng} \mathrm{m}^{-3}\right)$, followed by spring $\left(4.8 \pm 4.0 \mathrm{ng} \mathrm{m}^{-3}\right)$, winter $\left(4.5 \pm 3.2 \mathrm{ng} \mathrm{m}^{-3}\right)$ and summer $\left(3.8 \pm 3.9 \mathrm{ng} \mathrm{m}^{-3}\right)$. There was a weak but statistically significant negative correlation between the TGM concentration and ambient air temperature $(r=-0.08, p<0.05)$. Although the daytime temperature $\left(14.7 \pm 10.0^{\circ} \mathrm{C}\right)$ was sta-
\end{abstract}

tistically significantly higher than that in the nighttime $\left(13.0 \pm 9.8^{\circ} \mathrm{C}\right)(p<0.05)$, the daytime TGM concentration $\left(5.3 \pm 4.7 \mathrm{ng} \mathrm{m}^{-3}\right)$ was statistically significantly higher than that in the nighttime $\left(4.7 \pm 4.7 \mathrm{ng} \mathrm{m}^{-3}\right)(p<0.01)$, possibly due to local emissions related to industrial activities and activation of local surface emission sources. The observed $\Delta \mathrm{TGM} / \Delta \mathrm{CO}$ was significantly lower than that of Asian long-range transport, but similar to that of local sources in Korea and in US industrial events, suggesting that local sources are more important than those of long-range transport. CPF, CBPF and TPSCF indicated that the main sources of TGM were iron and manufacturing facilities, the hazardous waste incinerators and the coastal areas. 


\section{Introduction}

Mercury $(\mathrm{Hg})$ is an environmental toxic and bioaccumulative trace metal whose emissions to the environment have considerably increased due to anthropogenic activities such as mining and combustion processes (Pirrone et al., 2013; Streets et al., 2011). Hg can be globally distributed from the sources through atmospheric transport in a gaseous elemental form (Bullock et al., 1998; Mason and Sheu, 2002). However, the origins of atmospheric mercury are local and regional (Choi et al., 2009) as well as hemispherical and global (Durnford et al., 2010). In addition to the general background concentration of $\mathrm{Hg}$ in the global atmosphere, local $\mathrm{Hg}$ emissions contribute to the $\mathrm{Hg}$ burden and to the background concentration, much of which represents anthropogenic releases accumulated over the decades (UNEP, 2002).

$\mathrm{Hg}$ in the atmosphere exists in three major inorganic forms, including gaseous elemental mercury (GEM, $\mathrm{Hg}^{0}$ ), gaseous oxidized mercury $\left(\mathrm{GOM}, \mathrm{Hg}^{2+}\right)$ and particulate bound mercury (PBM, $\mathrm{Hg}(\mathrm{p})$ ). GEM, which is the dominant form of $\mathrm{Hg}$ in ambient air ( $>95 \%)$, has a relatively long residence time (0.5-2 years) due to its low reactivity and solubility (Schroeder and Munthe, 1998). However, GOM has high water solubility and relatively strong surface adhesion properties (Han et al., 2005), so it has a short atmospheric residence time (days). PBM is associated with airborne particles such as dust, soot, sea-salt aerosols and ice crystals (Lu and Schroeder, 2004) and is likely produced, in part, by adsorption of GOM species such as $\mathrm{HgCl}_{2}$ onto atmospheric particles (Gauchard et al., 2005; Lu and Schroeder, 2004; Sakata and Marumoto, 2005; Seo et al., 2012, 2015).

Atmospheric $\mathrm{Hg}$ released from natural (e.g., volcanoes, volatilization from aquatic and terrestrial environments) (Pirrone et al., 2010; Strode et al., 2007) and anthropogenic sources (e.g., coal combustion, cement production, ferrous and non-ferrous metals manufacturing facilities, waste incineration and industrial boilers) (Pacyna et al., 2003, 2006, 2010; Pirrone et al., 2010; Zhang et al., 2015) when introduced into terrestrial and aquatic ecosystem through wet and dry deposition (Mason and Sheu, 2002) can undergo various physical and chemical transformations before being deposited. Its lifetime in the atmosphere depends on its reactivity and solubility so that, depending on its form, it can have impacts on local, regional and global scales (Lin and Pehkonen, 1999; Lindberg et al., 2007). A portion of the $\mathrm{Hg}$ deposited in terrestrial environments through direct industrial discharge or atmospheric deposition is transported to aquatic system through groundwater and surface water runoff (Miller et al., 2013). A previous study also reported that $\mathrm{Hg}$ directly released into terrestrial and aquatic ecosystems from industrial effluent has influenced surface water, sediment and biological tissue (Flanders et al., 2010). Significant spatial variations in atmospheric $\mathrm{Hg}$ deposition near urban and industrial areas are due to local anthropogenic sources including municipal waste incinerators, medical waste incinerators, elec- tric power generating facilities and cement kilns (Dvonch et al., 1998), ferrous and non-ferrous metal processing, iron and steel manufacturing facilities, oil and coal combustion (Hoyer et al., 1995), and other forms of industrial combustion (Brown et al., 2015). Miller et al. (2013) also reported that local sources of elemental $\mathrm{Hg}$ are typically industrial processes including retort facilities used in the mercury mining industry to convert $\mathrm{Hg}$ containing minerals to elemental $\mathrm{Hg}$ and chlor-alkali facilities.

The annual average national anthropogenic $\mathrm{Hg}$ emissions from South Korea in 2007 have been estimated to be $12.8 \mathrm{t}$ (range 6.5 to $20.2 \mathrm{t}$ ); the major emission sources are coal combustion in thermal power plants $(25.8 \%)$, oil refineries $(25.5 \%)$, cement kilns $(21 \%)$, incinerators $(19.3 \%)$ including sludge incinerators $(4.7 \%)$, municipal waste incinerators (MWIs) (3\%), industrial waste incinerators (IWIs) $(2.7 \%)$, hospital/medical/infectious waste incinerators (HMIWIs) $(8.8 \%)$ and iron manufacturing (7\%) (Kim et al., 2010). Global anthropogenic Hg emissions were estimated to be $1960 \mathrm{t}$ in 2010 with east and southeast Asia responsible for $777 \mathrm{t}$ (39.7\%) (19.6t for Japan and 8.0 $\mathrm{t}$ for South Korea) (AMAP/UNEP, 2013). China is the largest Hgemitting country in the world, contributing more than $800 \mathrm{t}$ $(-40 \%)$ of the total anthropogenic $\mathrm{Hg}$ emissions (UNEP, 2008).

Background atmospheric $\mathrm{Hg}$ concentrations in the Northern Hemisphere have decreased since 1996 (Slemr et al., 2003), as measured at the Global Atmosphere Watch (GAW) station at Mace Head, Ireland (Ebinghaus et al., 2011), and at the Canadian Atmospheric Mercury Network (CAMNet) (Temme et al., 2007). In urban areas in South Korea atmospheric TGM concentrations have also decreased over the last few decades due to the reduced fossil fuel (mainly anthracite coal) consumption (Kim et al., 2016; Kim and $\mathrm{Kim}, 2000$ ). However, this decreasing trend is inconsistent with steady or increasing global anthropogenic Hg emissions since 1990 in the Northern Hemisphere (Streets et al., 2011; Weigelt et al., 2015; Wilson et al., 2010). A previous study reported that the global anthropogenic $\mathrm{Hg}$ emissions are increasing with an average of $1.3 \%$ annual growth without including the artisanal and small-scale production sector (Muntean et al., 2014).

Receptor models are often used to identify sources of air pollutants and are focused on the pollutants' behavior in the ambient environment at the point of impact (Hopke, 2003). In a previous study, the conditional probability function (CPF), which utilizes the local wind direction, and potential source contribution function (PSCF), which utilizes longer backward trajectories (typically 3-5 days), combined with concentration data were used to identify possible transport pathways and source locations (Hopke, 2003). While PSCF has been used primarily to identify regional sources, it has also been used to identify local sources (Hsu et al., 2003).

The objectives of this study were to characterize the hourly and seasonal variations of atmospheric TGM (the sum of the 
GEM and the GOM) concentrations; to identify the relationships between TGM and co-pollutant concentrations; and to identify likely source directions and locations of TGM using $\mathrm{CPF}$, the conditional bivariate probability function (CBPF) and total PSCF (TPSCF).

\section{Materials and methods}

\subsection{Sampling and analysis}

TGM concentrations were measured on the roof of the Korean Federation of Community Credit Cooperatives (KFCCC) building (latitude: $35.992^{\circ}$; longitude: $129.404^{\circ}$; $10 \mathrm{~m}$ above ground) in Pohang city, in Gyeongsangbuk-do, a province in eastern South Korea. Gyeongsangbuk-do has a population of 2.7 million ( $5 \%$ of the total population and the third-most-populated province in South Korea) and an area of $19030 \mathrm{~km}^{2}$ (19\% of the total area of South Korea and the largest province geographically in South Korea). Pohang city has a population of 500000 (1\% of the total population in South Korea) and an area of $605.4 \mathrm{~km}^{2}(1.1 \%$ of the total area in South Korea). It is heavily industrialized with the third-largest steel manufacturing facility in Asia and the fifthlargest in the world. There are several iron and steel manufacturing facilities including electric and sintering furnaces using coking in Gyeongsangbuk-do, including Pohang. In addition, there are several coke plants around the sampling site. The Hyungsan River divides the city into a residential area and the steel complex. Hg emissions data from iron and steel manufacturing and a hazardous waste incinerator were estimated based on a previous study (Kim et al., 2010) (Fig. 1).

TGM concentrations were measured every 5 min during summer (17-23 August 2012), fall (9-17 October 2012), winter (22-29 January 2013) and spring (26 March3 April 2013) using a mercury vapor analyzer (Tekran 2537B) which has two gold cartridges that alternately collect and thermally desorb mercury. Ambient air at a flow rate of $1.5 \mathrm{~L} \mathrm{~min}^{-1}$ was transported through a $3 \mathrm{~m}$ long heated sampling line ( $1 / 4^{\prime \prime}$ OD Teflon) into the analyzer. The sampling line was heated at about $50{ }^{\circ} \mathrm{C}$ using heat tape to prevent water condensation in the gold traps because moisture on gold surfaces interferes with the amalgamation of $\mathrm{Hg}$ (Keeler and Barres, 1999). Particulate matter was removed from the sampling line by a $47 \mathrm{~mm}$ Teflon filter.

\subsection{Meteorological data}

Hourly meteorological data (air temperature, relative humidity, and wind speed and direction) were obtained from the automatic weather station (AWS) operated by the Korea Meteorological Administration (KMA) (http://www.kma.go.kr) (6 km from the site). Hourly concentrations of $\mathrm{NO}_{2}, \mathrm{O}_{3}, \mathrm{CO}$, $\mathrm{PM}_{10}$ and $\mathrm{SO}_{2}$ were obtained from the National Air Quality Monitoring Network (NAQMN) (3 km from the site) (Fig. 1).
Meteorological Setting. Figure S1 shows the frequency of counts of measured wind direction occurrence by season during the sampling period. The predominant wind direction at the sampling site was W (20.9\%) and WS (19.2\%), and calm conditions of wind speed less than $1 \mathrm{~m} \mathrm{~s}^{-1}$ occurred $7.6 \%$ of the time. Compared to other seasons, however, the prevailing winds in summer were N (17.0\%), NE (16.4\%), S (16.4\%), and SW $(15.8 \%)$.

\subsection{QA/QC}

Automated daily calibrations were carried out for the Tekran 2537B using an internal permeation source. Two-point calibrations (zero and span) were separately performed for each gold cartridge. Manual injections were performed prior to every field sampling campaign to evaluate these automated calibrations using a saturated mercury vapor standard. The relative percent difference (RPD) between automated calibrations and manual injections was less than $2 \%$. The recovery measured by directly injecting known amounts of four mercury vapor standards when the sample line was connected to zero air ranged from 92 to $110 \%(99.4 \pm 5.2 \%$ in average).

\section{Model descriptions}

\subsection{Conditional probability function}

CPF was originally performed to determine which wind directions dominate during high concentration events to evaluate local source impacts (Ashbaugh et al., 1985). It has been successfully used in many previous studies (Begum et al., 2004; Kim et al., 2003a, b; Xie and Berkowitz, 2006; Zhao et al., 2004; Zhou et al., 2004). CPF estimates the probability that the measured concentration will exceed the threshold criterion for a given wind direction. CPF is defined as follows:

$\mathrm{CPF}_{\Delta \theta}=\frac{\left.m_{\Delta \theta}\right|_{C \geq x}}{n_{\Delta \theta}}$,

where $m_{\Delta \theta}$ is the number of samples from the wind sector $\theta$ having concentration $\mathrm{C}$ greater than or equal to a threshold value $x$, and $n_{\Delta \theta}$ is the total number of samples from wind sector $\Delta \theta$. In this study, 16 sectors $\left(\Delta \theta=22.5^{\circ}\right)$ were used and calm winds $\left(\leq 1 \mathrm{~m} \mathrm{~s}^{-1}\right)$ were excluded from the analysis. The threshold criterion was set at above the overall average TGM concentration $\left(5.0 \mathrm{ng} \mathrm{m}^{-3}\right)$. Thus, CPF indicates the potential for winds from a specific direction to contribute to high air pollution concentrations.

\subsection{Conditional bivariate probability function}

CBPF couples ordinary $\mathrm{CPF}$ with wind speed as a third variable, allocating the measured concentration of pollutant to cells defined by ranges of wind direction and wind speed rather than to only wind direction sectors. 


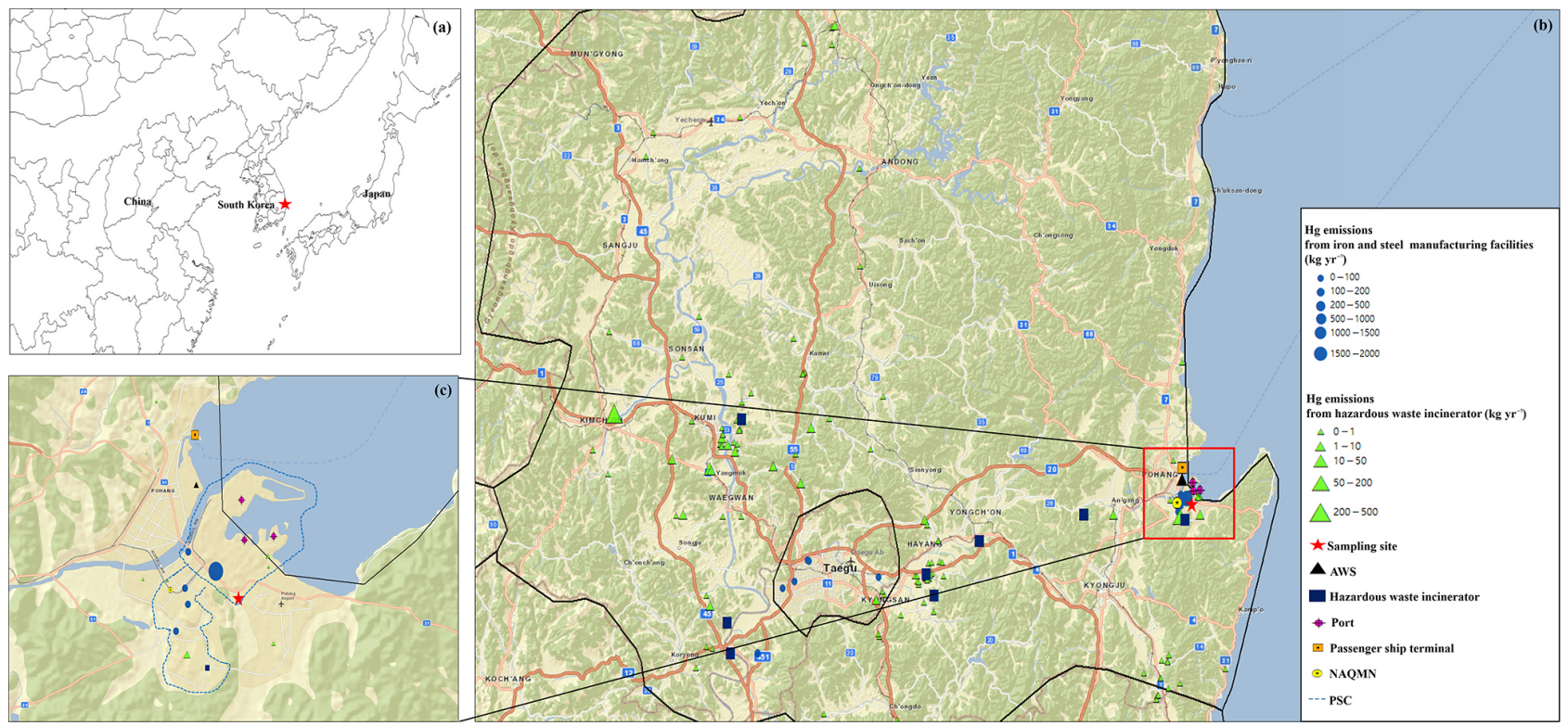

Figure 1. The location of sampling site in this study (a, South Korea; b, Gyeongsangbuk-do; and c, Pohang). AWS, NAQMN and PSC represent automatic weather station, National Air Quality Monitoring Network and Pohang steel complex, respectively.

$\mathrm{CBPF}$ is defined as follows:

$\mathrm{CBPF}_{\Delta \theta, \Delta u}=\frac{\left.m_{\Delta \theta, \Delta u}\right|_{C \geq x}}{n_{\Delta \theta, \Delta u}}$

where $m_{\Delta \theta, \Delta u}$ is the number of samples in the wind sector $\Delta \theta$ with wind speed interval $\Delta u$ having concentration $C$ greater than a threshold value $x$, and $n_{\Delta \theta \Delta u}$ is the total number of samples in that wind direction-speed interval. The threshold criterion was set at above the overall average TGM concentration $\left(5.0 \mathrm{ng} \mathrm{m}^{-3}\right)$. The extension to the bivariate case can provide more information on the nature of the sources because different source types such as stack emission sources and ground-level sources can have different wind speed dependencies (prominent at high and low wind speed, respectively). More detailed information is described in a previous study (Uria-Tellaetxe and Carslaw, 2014).

\subsection{Potential source contribution function}

The PSCF model has been extensively and successfully used in previous studies to identify the likely source areas (Cheng et al., 1993; Han et al., 2004; Hopke et al., 2005; Lai et al., 2007; Lim et al., 2001; Poissant, 1999; Zeng and Hopke, 1989). PSCF is a simple method that links residence time in upwind areas with high concentrations through a conditional probability field and was originally developed by Ashbaugh et al. (1985). $\mathrm{PSCF}_{i j}$ is the conditional probability that an air parcel that passed through the $i j$ th cell had a high concentration upon arrival at the monitoring site and is defined as follows:

$\operatorname{PSCF}_{i j}=\frac{m_{i j}}{n_{i j}}$, where $n_{i j}$ is the number of trajectory segment end points that fall into the $i j$ th cell, and $m_{i j}$ is the number of segment end points in the same grid cell ( $i j$ th cell) when the concentrations are higher than a criterion value as measured at the sampling site.

High PSCF values in those grid cells are regarded as possible source locations. Cells including emission sources can be identified with conditional probabilities close to 1 if trajectories that have crossed the cells efficiently transport the released pollutant to the receptor site. Therefore, the PSCF model provides a tool to map the source potentials of geographical areas.

The criterion value of PSCF for TGM concentration was set at above the overall average concentration $\left(5.0 \mathrm{ng} \mathrm{m}^{-3}\right)$ to identify the emission sources associated with high TGM concentrations and to provide a better estimation and resolution of source locations during the sampling periods. The geographic area covered by the computed trajectories was divided into an array of $0.05^{\circ}$ latitude by $0.05^{\circ}$ longitude grid cells. As will be discussed in Section 5.3, $24 \mathrm{~h}$ backward trajectories starting at every hour at a height of 10,50 and $100 \mathrm{~m}$ above ground level were computed using the vertical velocity model because local sources are more important than those of long-range transport in this study. (It should be noted that PSCF results using $48 \mathrm{~h}$ backward trajectories had similar results to the $24 \mathrm{~h}$ backward trajectories.) Each trajectory was terminated if they exit the model top $(5000 \mathrm{~m})$, but advection continues along the surface if trajectories intersect the ground. To generate horizontally highly resolved meteorological inputs for trajectory calculations, the Weather Research and Forecast (WRF) model was used to generate 
a coarse domain at a resolution of $27 \mathrm{~km}$ and a nested domain at a horizontal resolution of $9 \mathrm{~km}$, which geographically cover northeast Asia and the southern part of the Korean Peninsula, respectively. The nested domain has 174 columns in the east-west direction and 114 rows in the north-south direction. PSCF was calculated with $9 \mathrm{~km}$ meteorological data.

In this study, TPSCF, which incorporates probability from above different starting heights, was calculated since backward trajectories starting at different heights traverse different distances and pathways, thus providing information that cannot be obtained from a single starting height (Cheng et al., 1993).

Previous studies suggest that there are increasing uncertainties as backward-trajectory distances increase (Stohl et al., 2002) and that PSCF modeling is prone to the trailing effect in which locations upwind of sources are also identified as potential sources (Han et al., 2004). An alternative to back-trajectory calculations is the interpretation of atmospheric trace substance measurements (Stohl et al., 2002), although this technique does not provide much information on source locations.

Generally, PSCF results show that the potential sources covered wide areas instead of indicating individual sources due to the trailing effect. The trailing effect appears since PSCF distributes a constant weight along the path of the trajectories. To minimize the effect of small $n_{i j}$ (the number of trajectory segment end points that fall into the $i j$ th cell) values, resulting in high TPSCF values with high uncertainties, an arbitrary weight function $W\left(n_{i j}\right)$ was applied to downweight the PSCF values for the cell in which the total number of end points was less than 3 times the average value of the end points (Choi et al., 2011; Heo et al., 2009; Hopke et al., 1995; Polissar et al., 2001). The TPSCF value for a grid cell was defined as follows:

$$
\begin{aligned}
& P\left(\mathrm{TPSCF}_{i j}\right)= \\
& \frac{P\left(m_{i j}\right)_{10 \mathrm{~m}}+P\left(m_{i j}\right)_{50 \mathrm{~m}}+P\left(m_{i j}\right)_{100 \mathrm{~m}}}{P\left(n_{i j}\right)_{10 \mathrm{~m}}+P\left(n_{i j}\right)_{50 \mathrm{~m}}+P\left(n_{i j}\right)_{100 \mathrm{~m}}} \times W,
\end{aligned}
$$

where

$$
W\left(n_{i j}\right)=\left\{\begin{array}{l}
1.0,3 n_{\text {ave }}<n_{i j} \\
0.8,2 n_{\text {ave }}<n_{i j} \leq 3 n_{\text {ave }} \\
0.6, n_{\text {ave }}<n_{i j} \leq 2 n_{\text {ave }} \\
0.4,0.5 n_{\text {ave }}<n_{i j} \leq n_{\text {ave }} \\
0.2, n_{i j} \leq 0.5 n_{\text {ave }}
\end{array} .\right.
$$

\section{Clean Air Policy Support System (CAPSS) data}

In this study, the Korean National Emission Inventory estimated using CAPSS data developed by the National Institute of Environmental Research (NIER) was used (http:// airemiss.nier.go.kr/main.jsp; last access: 9 December 2015). CAPSS is the national emission inventory system for the air pollutants $\mathrm{CO}, \mathrm{NO}_{x}, \mathrm{SO}_{x}, \mathrm{TSP}, \mathrm{PM}_{10}, \mathrm{PM}_{2.5}$, VOCs and $\mathrm{NH}_{3}$ which utilizes various national, regional and local statistical data collected from about 150 organizations in Korea. In CAPSS, the source classification category (SCC) excluding fugitive dust and biomass burning based on the European Environment Agency's (EEA) CORe Inventory of AIR emissions was classified into the following three levels (EMEP/CORINAIR) (NIER, 2011).

1. the upper level (SCC1): 11 source categories;

2. the intermediate level (SCC2): 42 source categories;

3. the lower level (SCC3): 173 source categories.

The sectoral contributions of emissions of South Korea, Gyeongsangbuk-do and Pohang for $\mathrm{CO}, \mathrm{NO}_{x}, \mathrm{SO}_{x}$, TSP, $\mathrm{PM}_{10}, \mathrm{PM}_{2.5}$, VOC and $\mathrm{NH}_{3}$ are shown in Fig. S2 (see Supplement for details).

More detailed information about SCCs in CAPSS is described in Table S1 in the Supplement.

\section{Results and discussions}

\subsection{General characteristics of TGM}

The seasonal distributions of TGM were characterized by large variability during each sampling period (Fig. 2). The average concentration of TGM during the complete sampling period was $5.0 \pm 4.7 \mathrm{ng} \mathrm{m}^{-3}$ (range: $1.0-79.6 \mathrm{ng} \mathrm{m}^{-3}$ ). This is significantly higher than the Northern Hemisphere background concentration $\left(-1.5 \mathrm{ng} \mathrm{m}^{-3}\right.$ ) (Sprovieri et al., 2010) and those measured in China, in Japan and other locations in Korea but lower than those measured at Changchun, Gui Yang and Nanjing in China (Table 1). The median TGM concentration was $3.6 \mathrm{ng} \mathrm{m}^{-3}$, which was much lower than that of the average, suggesting that there were some extreme pollution episodes with very high TGM concentrations.

The TGM concentration follows a typical log-normal distribution (Fig. S3 in Supplement). The range of 2 to $5 \mathrm{ng} \mathrm{m}^{-3}$ dominated the distribution, accounting for more than half of the total number of samples $(60.8 \%)$. The maximum frequency of $28.1 \%$ occurred between 2 and $3 \mathrm{ng} \mathrm{m}^{-3}$. Extremely high TGM concentration events $\left(>20 \mathrm{ng} \mathrm{m}^{-3}\right)$ were also observed (1.7\% of the time).

\subsection{Seasonal variations}

The TGM concentration was statistically significantly higher in fall $\left(6.7 \pm 6.4 \mathrm{ng} \mathrm{m}^{-3}\right) \quad(p<0.01)$, followed by spring $\left(4.8 \pm 4.0 \mathrm{ng} \mathrm{m}^{-3}\right)$, winter $\left(4.5 \pm 3.2 \mathrm{ng} \mathrm{m}^{-3}\right)$ and summer $\left(3.8 \pm 3.9 \mathrm{ng} \mathrm{m}^{-3}\right)$ (Table 2). The highest concentrations $\left(\mathrm{TGM}>10 \mathrm{ng} \mathrm{m}^{-3}\right.$ ) were measured more frequently in fall $(24.7 \%)$, and the lowest concentrations $\left(\mathrm{TGM}<3 \mathrm{ng} \mathrm{m}^{-3}\right.$ ) mainly occurred in summer $(49.7 \%)$. The low TGM concentration in summer is likely because of increased mixing 
Table 1. Comparison with previous studies for TGM concentrations.

\begin{tabular}{lllrll}
\hline Country & Location & Sampling period & $\begin{array}{r}\text { TGM conc. } \\
\left(\mathrm{ng} \mathrm{m}^{-3}\right)\end{array}$ & Classifications & Reference \\
\hline China & Mt. Hengduan, Qinghai-Tibet Plateau & Jul 2010-Oct 2010 & 2.5 & Remote & Fu et al. (2015) \\
China & Nanjing, Jiangsu & Jan 2011-Oct 2011 & 7.9 & Urban & Hall et al. (2014) \\
China & Mt. Dinghu, Guangdong & Oct 2009-Apr 2010 & 5.1 & Rural & Chen et al. (2013) \\
China & Guangzhou, Guangdong & Nov 2010-Nov 2011 & 4.6 Urban & Chen et al. (2013) \\
China & Gui Yang, Guizhou & Jan 2010-Feb 2010 & 8.4 & Urban & Feng et al. (2004) \\
China & Changchun, Jilin & Jul 1999-Jul 2000 & 13.5-25.4 & Urban & Fang et al. (2004) \\
Japan & Fukuoka & Jun 2012-May 2013 & 2.3 & Urban & Marumoto et al. (2015) \\
Japan & Tokai-mura & Oct 2005-Aug 2006 & 3.8 Suburban & Osawa et al. (2007) \\
Japan & Tokyo & Apr 2000-Mar 2001 & 2.7 & Urban & Sakata and Marumoto (2002) \\
Korea & Seoul & 1987-2013 & 3.7 & Urban & Kim et al. (2016) \\
Korea & Gangwon-do, Chuncheon & 2006-2009 & 2.1 & Rural & Han et al. (2014) \\
Korea & Seoul & Feb 2005-Feb 2006 & 3.2 & Urban & Kim et al. (2009) \\
Korea & Seoul & Feb 2005-Dec 2006 & 3.4 & Urban & Choi et al. (2009) \\
Korea & Seoul & 19-29 Sep 1997 & 3.6 & Urban & Kim and Kim (2001) \\
& & 27 May 1998-Jun 1998 & & & This study \\
Korea & Gyeongsangbuk-do, Pohang & 17-23 Aug 2012 & 5.0 & Urban & \\
& & 9-17 Oct 2012 & & & \\
& & 22-29 Jan 2013 & 26 Mar 2013-3 Apr 2013 & &
\end{tabular}

height (Friedli et al., 2011) and gas phase oxidation (Choi et al., 2013; Huang et al., 2010; Lynam and Keeler, 2006) at higher temperatures particularly at this sampling site, which is close to the ocean $(2 \mathrm{~km})$, where oxidation involving halogens may be enhanced (Holmes et al., 2009; Lin et al., 2006). The high TGM concentrations in fall were due to different wind direction (see Fig. S1), sources, relationships with other pollutants and meteorological conditions. More detailed information can be found in Sect. 5.4.

The average concentrations of $\mathrm{NO}_{2}, \mathrm{O}_{3}, \mathrm{CO}, \mathrm{PM}_{10}$ and $\mathrm{SO}_{2}$ during the complete sampling period were $23.1 \pm 10.8 \mathrm{ppbv}, \quad 24.6 \pm 12.5 \mathrm{ppbv}, \quad 673.7 \pm 487.3 \mathrm{ppbv}$, $55.5 \pm 26.4 \mu \mathrm{g} \mathrm{m}^{-3}$ and $6.7 \pm 4.3 \mathrm{ppbv}$, respectively. $\mathrm{NO}_{2}$, $\mathrm{O}_{3}, \mathrm{CO}, \mathrm{PM}_{10}$ and $\mathrm{SO}_{2}$ concentrations were highest in spring (Table 2). There was a statistically significant positive correlation between the TGM and $\mathrm{PM}_{10}(r=0.10, p<0.01)$. However, the TGM concentration was not significantly correlated with $\mathrm{NO}_{2}, \mathrm{CO}$ or $\mathrm{SO}_{2}$ concentrations, suggesting that combustion associated with space heating was not a significant source of TGM (Choi et al., 2009).

\subsection{Relationship between TGM and CO}

CO has a significant anthropogenic source and is considered to be an indicator of anthropogenic emissions (Mao et al., 2008). A previous study has reported that TGM and CO have a strong correlation because they have similar emission sources (combustion processes) and similar long atmospheric residence times (Weiss-Penzias et al., 2003).

There was a weak positive correlation between TGM and $\mathrm{CO}$ in this study $(r=0.04, p=0.27)$. However there was a statistically significant correlation between TGM and CO in winter $(r=0.25, p<0.05)$, suggesting that TGM and $\mathrm{CO}$ were affected by similar, possibly distant, anthropogenic emission sources in winter.

On the other hand, there were no statistically significant correlations between TGM and CO in spring $(r=0.02, p=$ $0.78)$, in summer ( $r=0.13, p=0.08)$ or in fall $(r=-0.03$, $p=0.69)$, indicating that TGM and CO were affected by different anthropogenic emission sources in these seasons.

Previous studies identified the long-range transport of mercury using the $\Delta \mathrm{TGM} / \triangle \mathrm{CO}$ enhancement ratio (Choi et al., 2009; Jaffe et al., 2005; Kim et al., 2009; WeissPenzias et al., 2003; Weiss-Penzias et al., 2006). Kim et al. (2009) and Choi et al. (2009) investigated high concentration events which were defined as at least a $10 \mathrm{~h}$ period with hourly average TGM and CO concentrations higher than the monthly average TGM and CO concentrations. They reported that long-range transport events were characterized by high values of TGM/CO ratio ( $\triangle \mathrm{TGM} / \Delta \mathrm{CO})\left(0.0052-0.0158 \mathrm{ng} \mathrm{m}^{-3} \mathrm{ppb}^{-1}\right)$ and high correlations $\left(r^{2}>0.5\right)$, whereas local events showed low $\Delta \mathrm{TGM} / \Delta \mathrm{CO}\left(0.0005 \mathrm{ng} \mathrm{m}^{-3} \mathrm{ppb}^{-1}\right.$ in average $)$ and weak correlations $\left(r^{2}<0.5\right)$.

The observed $\Delta$ TGM / $\triangle \mathrm{CO}$ was $0.0001 \mathrm{ng} \mathrm{m}^{-3} \mathrm{ppb}^{-1}$ in spring, 0.0005 in summer, -0.0007 in fall and $0.0011 \mathrm{ng} \mathrm{m}^{-3} \mathrm{ppb}^{-1}$ in winter, which are significantly lower than that indicative of Asian long-range transport (0.0046$0.0056 \mathrm{ng} \mathrm{m}^{-3} \mathrm{ppb}^{-1}$ ) (Friedli et al., 2004; Jaffe et al., 2005; Weiss-Penzias et al., 2006), suggesting that local sources are more important than those of long-range transport in this study. The $\triangle \mathrm{TGM} / \Delta \mathrm{CO}$ in winter $\left(0.0011 \mathrm{ng} \mathrm{m}^{-3} \mathrm{ppb}^{-1}\right)$ was similar to that of a site impacted by local sources in Ko- 

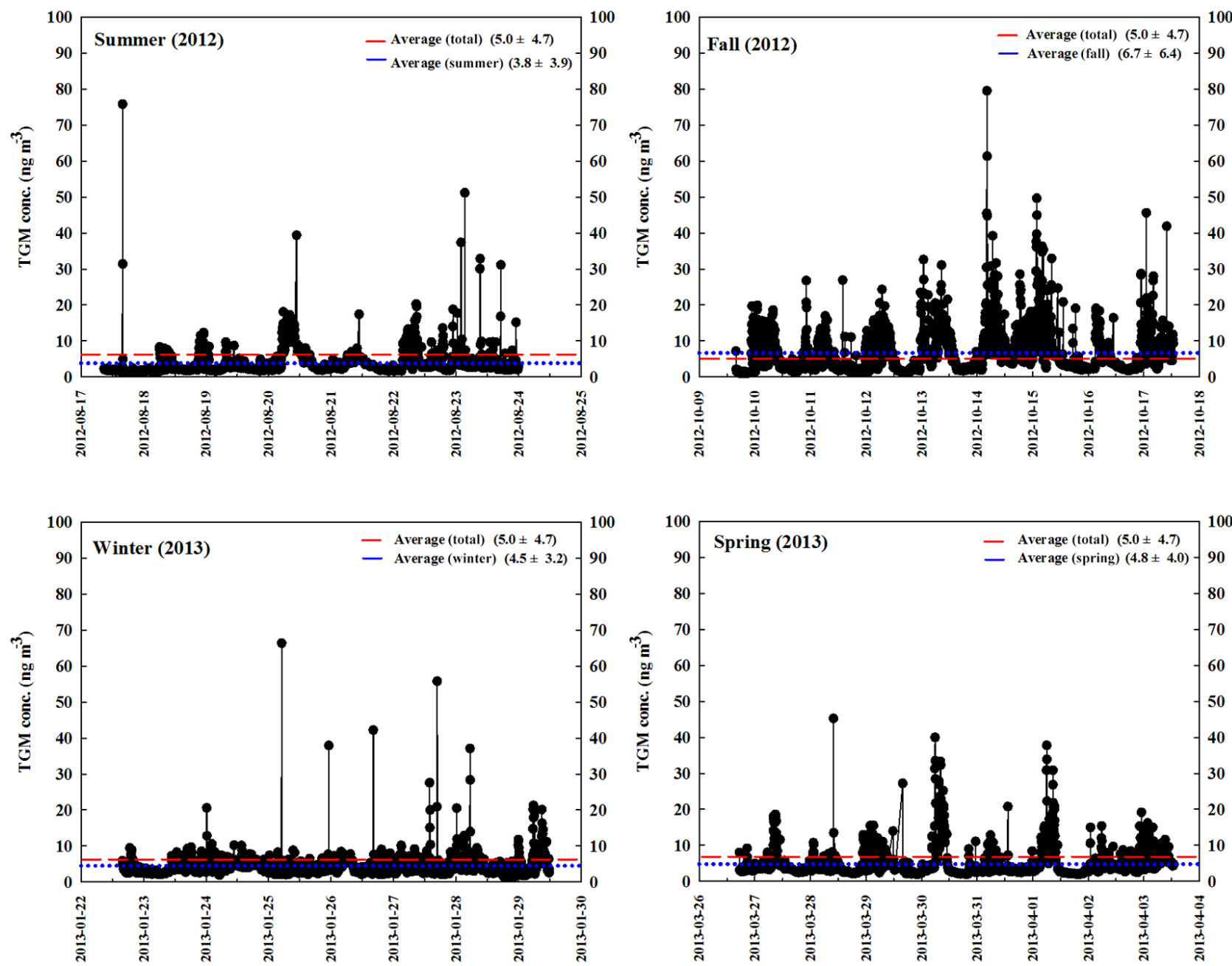

Figure 2. Time series of TGM concentrations in this study.

rea (Kim et al., 2009) and in US industrially related events $\left(0.0011 \mathrm{ng} \mathrm{m}^{-3} \mathrm{ppb}^{-1}\right)$ (Weiss-Penzias et al., 2007).

There are also uncertainties from the potential mixing between $\mathrm{Hg}$ associated with long-range transported airflows and local air making it difficult to distinguish between distant and local source impacts. However, it is possible that the 1-week sampling period in each season did not capture the long-range transport events, and more can be learned using a larger dataset than just using the 1-week sampling period to confirm these results.

\subsection{Diurnal variations}

Diurnal variations of TGM (Fig. 3), co-pollutants concentrations and meteorological data were observed (Fig. S4). $\mathrm{TGM}, \mathrm{O}_{3}, \mathrm{CO}, \mathrm{SO}_{2}$ and temperature in the daytime (06:0018:00 LT (local time)) were higher than those in the nighttime (18:00-06:00 LT) $(p<0.05)$, except for $\mathrm{PM}_{10}(p=0.09)$ (Fig. S5). However, $\mathrm{NO}_{2}$ during the nighttime because of relatively lower photochemical reactivity with $\mathrm{O}_{3}$ was higher than that in the daytime $(p<0.05)$ (Adame et al., 2012).

The daytime TGM concentration $\left(5.3 \pm 4.7 \mathrm{ng} \mathrm{m}^{-3}\right)$ was higher than that in the nighttime $\left(4.7 \pm 4.7 \mathrm{ng} \mathrm{m}^{-3}\right)$ $(p<0.01)$, which was similar to several previous studies (Cheng et al., 2014; Gabriel et al., 2005; Nakagawa, 1995; Stamenkovic et al., 2007) but different than another study (Lee et al., 1998). Previous studies reported that this difference is due to local sources close to the sampling site (Cheng et al., 2014; Gabriel et al., 2005), a positive correlation between TGM concentration and ambient air temperature (Nakagawa, 1995) and increased traffic (Stamenkovic et al., 2007). However, another study suggested that the higher TGM concentration during the night was due to the shallowing of the boundary layer, which concentrated the TGM near the surface (Lee et al., 1998).

In a previous study the daytime TGM concentration was relatively lower than that in the nighttime because the sea breeze transported air containing low amounts of TGM from 
Table 2. Summary of atmospheric concentrations of TGM and co-pollutants, and meteorological data. Note that TGM was measured every $5 \mathrm{~min}$, and other pollutants and meteorological data were measured every $1 \mathrm{~h}$.

\begin{tabular}{|c|c|c|c|c|c|c|c|c|c|c|c|}
\hline & & $\begin{array}{r}\text { TGM } \\
\left(\mathrm{ng} \mathrm{m}^{-3}\right)\end{array}$ & $\begin{array}{l}\mathrm{NO}_{2} \\
(\mathrm{ppb})\end{array}$ & $\begin{array}{r}\mathrm{O}_{3} \\
(\mathrm{ppb})\end{array}$ & $\begin{array}{r}\mathrm{CO} \\
(\mathrm{ppb})\end{array}$ & $\begin{array}{r}\mathrm{PM}_{10} \\
\left(\mu \mathrm{g} \mathrm{m}^{-3}\right)\end{array}$ & $\begin{array}{r}\mathrm{SO}_{2} \\
(\mathrm{ppb})\end{array}$ & $\begin{array}{r}\text { Temperature } \\
\left({ }^{\circ}\right)\end{array}$ & $\begin{array}{l}\text { Wind speed } \\
\qquad\left(\mathrm{m} \mathrm{s}^{-1}\right)\end{array}$ & $\begin{array}{r}\text { Humidity } \\
(\%)\end{array}$ & $\begin{array}{l}\text { Solar radiation } \\
\qquad\left(\mathrm{MJ} \mathrm{m}^{-2}\right)\end{array}$ \\
\hline \multirow[t]{3}{*}{ Spring } & $\mathrm{N}$ & 2139 & 189 & 215 & 215 & 215 & 215 & 216 & 216 & 216 & 216 \\
\hline & Average & $4.8 \pm 4.0$ & $25.3 \pm 9.0$ & $29.4 \pm 14.2$ & $766.5 \pm 505.2$ & $70.1 \pm 26.0$ & $7.6 \pm 3.8$ & $10.5 \pm 4.2$ & $2.2 \pm 1.2$ & $56.2 \pm 16.8$ & $0.82 \pm 1.09$ \\
\hline & Range & $1.9-45.3$ & $8-55$ & $2-58$ & $300-3100$ & $28-204$ & $5-35$ & $1.1-21.6$ & $0.4-6.2$ & 19.0-94.0 & $0-3.44$ \\
\hline \multirow[t]{3}{*}{ Summer } & $\mathrm{N}$ & 1863 & 187 & 188 & 187 & 188 & 188 & 186 & 180 & 186 & 141 \\
\hline & Average & $3.8 \pm 3.9$ & $18.3 \pm 9.2$ & $18.9 \pm 10.1$ & $697.3 \pm 689.7$ & $35.1 \pm 15.8$ & $6.5 \pm 6.2$ & $26.6 \pm 4.2$ & $2.2 \pm 1.1$ & $82.5 \pm 13.9$ & $0.40 \pm 0.69$ \\
\hline & Range & $1.2-75.9$ & $4-44$ & $5-48$ & $200-3300$ & $12-87$ & $2-27$ & $19.7-34.1$ & $0.1-6.4$ & $43-98$ & $0-2.92$ \\
\hline \multirow[t]{3}{*}{ Fall } & $\mathrm{N}$ & 2226 & 212 & 212 & 212 & 212 & 211 & 216 & 216 & 216 & 216 \\
\hline & Average & $6.7 \pm 6.4$ & $25.0 \pm 7.8$ & $23.7 \pm 13.1$ & $662.7 \pm 350.2$ & $58.1 \pm 17.8$ & $5.3 \pm 3.5$ & $17.4 \pm 3.2$ & $2.1 \pm 0.8$ & $54.5 \pm 14.7$ & $0.62 \pm 0.90$ \\
\hline & Range & $1.0-79.6$ & 9-53 & 6-69 & $300-2900$ & $20-145$ & 3-39 & $11.7-25.2$ & $0.5-4.5$ & $12-79$ & 0-2.90 \\
\hline \multirow[t]{3}{*}{ Winter } & $\mathrm{N}$ & 1917 & 188 & 187 & 188 & 188 & 186 & 192 & 192 & 192 & 192 \\
\hline & Average & $4.5 \pm 3.2$ & $23.5 \pm 14.7$ & $26.1 \pm 8.7$ & $556.4 \pm 298.9$ & $56.3 \pm 30.5$ & $7.4 \pm 2.5$ & $1.1 \pm 4.3$ & $2.8 \pm 1.1$ & $46.3 \pm 24.5$ & $0.43 \pm 0.71$ \\
\hline & Range & $1.3-66.4$ & $5-74$ & $1-41$ & $200-2400$ & $18-161$ & $5-24$ & $-0.65-10.1$ & $0.5-6.0$ & $11-90$ & $0-2.34$ \\
\hline \multirow[t]{3}{*}{ Total } & $\mathrm{N}$ & 8145 & 776 & 802 & 802 & 803 & 800 & 810 & 804 & 810 & 765 \\
\hline & Average & $5.0 \pm 4.7$ & $23.1 \pm 10.8$ & $24.6 \pm 12.5$ & $673.7 \pm 487.3$ & $55.5 \pm 26.4$ & $6.7 \pm 4.3$ & $13.8 \pm 9.9$ & $2.3 \pm 1.1$ & $59.4 \pm 22.1$ & $0.59 \pm 0.90$ \\
\hline & Range & $1.0-79.6$ & $4-74$ & $1-69$ & $200-3300$ & $12-204$ & $2-39$ & $-6.5-34.1$ & $0.1-6.4$ & $11-98$ & $0-3.44$ \\
\hline
\end{tabular}

the ocean during the daytime, whereas the land breeze transported air containing relatively high concentrations of TGM from an urban area during the nighttime (Kellerhals et al., 2003). Although it is possible that the land-sea breeze may affect diurnal variations in TGM concentrations since the sampling site was near the ocean and lower TGM were also observed during the daytime, the higher concentrations in the daytime than those in nighttime were due to local emission sources because the daytime temperature $\left(14.7 \pm 10.0^{\circ} \mathrm{C}\right)$ was statistically significantly higher than that in the nighttime $\left(13.0 \pm 9.8^{\circ} \mathrm{C}\right)(t$ test, $p<0.05)$, and there was a weak but statistically significant negative correlation between TGM concentration and ambient air temperature $(r=-0.08, p<0.05)$. In addition, there are several known $\mathrm{Hg}$ sources such as iron and steel manufacturing facilities including electric and sintering furnaces using coking between the sampling site and the ocean.

As shown in Figs. 3 and S4, there was a weak but negative relationship between the TGM concentrations and $\mathrm{O}_{3}$ concentrations $(r=-0.18, p<0.01)$, suggesting that oxidation of GEM in the oxidizing atmosphere during periods of strong atmospheric mixing was partially responsible for the diurnal variations of TGM concentrations. In addition, oxidation of GEM by bromine species in the coastal area (Obrist et al., 2011) or by chloride radicals in the marine boundary layer (Laurier et al., 2003) might play a significant role. If oxidation of GEM occurred, GOM concentrations would increase. However there are uncertainties on the net effects on TGM (the sum of the GEM and the GOM) since we did not measure GOM concentrations.

TGM concentration was negatively correlated with ambient air temperature $(r=-0.08, p<0.05)$ because high ambient air temperature in the daytime will increase the height of the boundary layer and dilute the TGM, and the relatively lower boundary layer at nighttime could concentrate

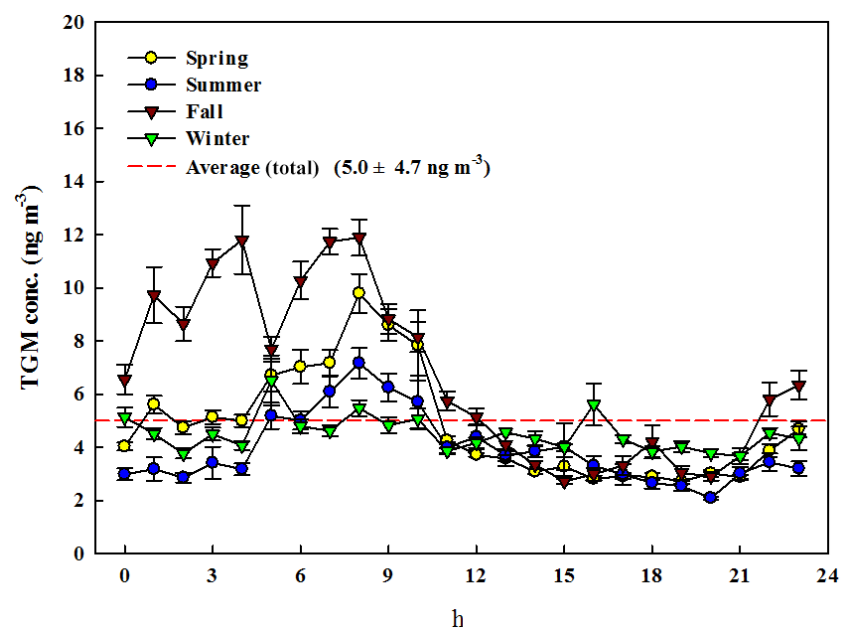

Figure 3. The diurnal variations of TGM concentrations during the sampling periods. The error bars represent standard error.

the TGM in the atmosphere ( $\mathrm{Li}$ et al., 2011). Although there was a statistically significant negative correlation between the TGM concentration and ambient air temperature, there was a rapid increase in TGM concentration between 06:00 and 09:00, when ambient temperatures also increased possibly due to local emissions related to industrial activities, increased traffic and activation of local surface emission sources. Similar patterns were found in previous studies (Li et al., 2011; Stamenkovic et al., 2007). Nonparametric correlations revealed that there is a weak positive correlation between TGM and ambient air temperature $\left(r_{\mathrm{s}}=0.11\right.$, $p=0.27$ ) between 06:00 and 09:00. The TGM concentration was negatively correlated with $\mathrm{O}_{3}\left(r_{\mathrm{s}}=-0.33, p<0.01\right)$ but positively correlated with $\mathrm{NO}_{2}\left(r_{\mathrm{s}}=0.21, p<0.05\right)$, suggesting that the increased traffic is the main source of TGM during these time periods. 

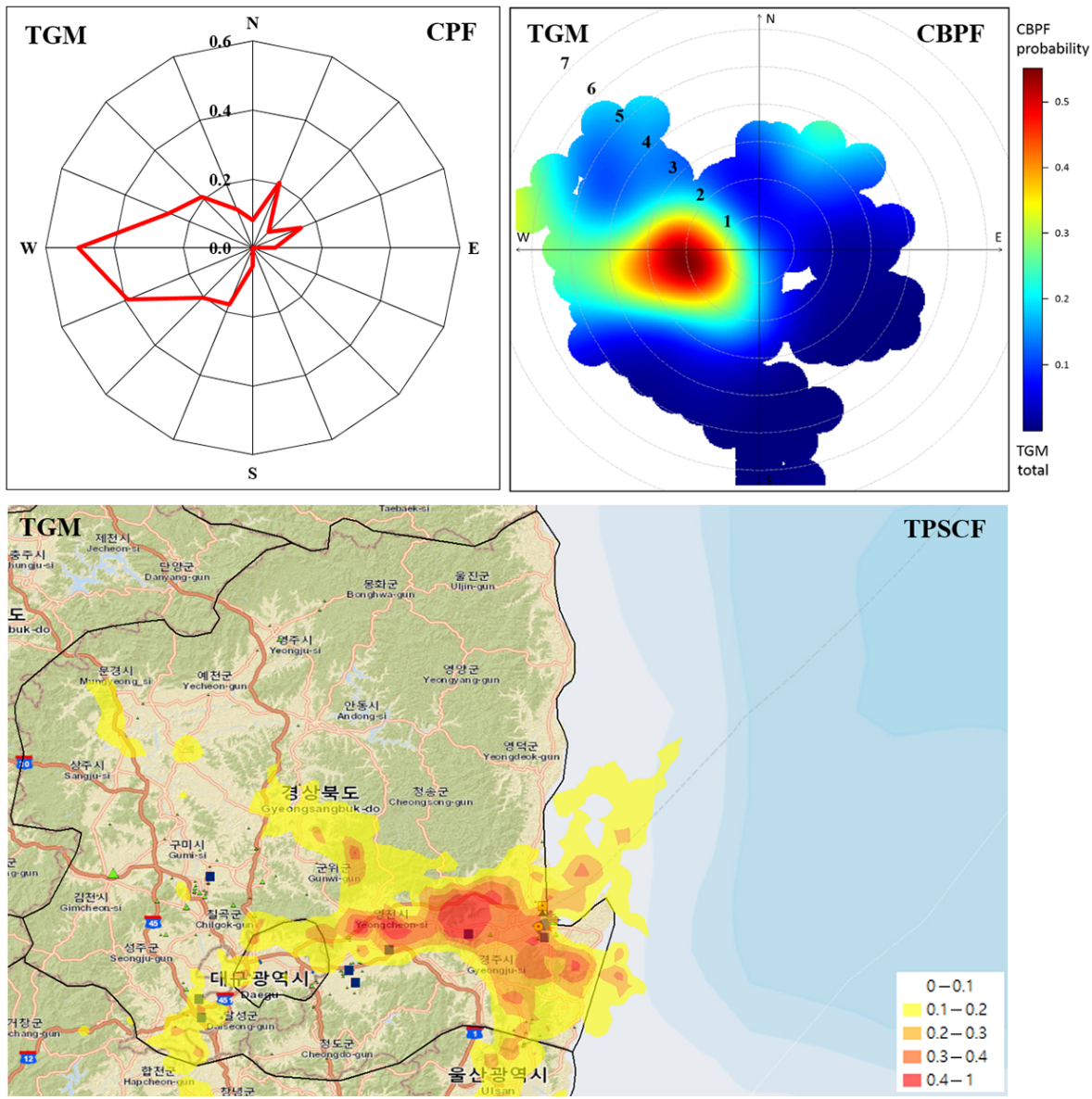

Figure 4. CPF, CBPF and TPSCF plots for TGM higher-than-average concentration. The radial axes of CPF and CBPF are the probability and the wind speed $\left(\mathrm{m} \mathrm{s}^{-1}\right)$, respectively.

Compared to other seasons, significantly different diurnal variations of TGM were observed in fall. The daytime TGM concentrations in fall were similar to those in other seasons; however, the nighttime TGM concentrations in fall were much higher than those in other seasons. As described earlier in Sect. 5.2, the high TGM concentrations in fall were possibly due to the relationship between other pollutants and meteorological conditions as well as different wind direction and sources. The nighttime TGM concentrations in fall were simultaneously positively correlated with $\mathrm{PM}_{10}$ $(r=0.26, p<0.05)$ and $\mathrm{CO}(r=0.21, p<0.05)$ concentrations and wind speed $(r=0.35, p<0.01)$, suggesting that the combustion process is an important source during this period.

TGM generally showed a consistent increase in the early morning (06:00-09:00) and a decrease in the afternoon (14:00-17:00), similar to previous studies (Dommergue et al., 2002; Friedli et al., 2011; Li et al., 2011; Liu et al., 2011; Mao et al., 2008; Shon et al., 2005; Song et al., 2009; Stamenkovic et al., 2007). Significantly different diurnal patterns have been observed at many suburban sites with the daily maximum occurring in the afternoon (12:00-15:00), possibly due to local emission sources and transport (Fu et al., 2008, 2010; Kuo et al., 2006; Wan et al., 2009). Other studies in Europe reported that TGM concentrations were relatively higher early in the morning or at night possibly due to mercury emissions from surface sources that accumulated in the nocturnal inversion layer (Lee et al., 1998; Schmolke et al., 1999).

Based on the above results, the diurnal variations in TGM concentration are due to a combination of (1) reactions with an oxidizing atmosphere, (2) changes in ambient temperature and (3) local emissions related to industrial activities. To supplement these conclusions, CPF and CBPF were used to identify source directions, and TPSCF was used to identify potential source locations.

\subsection{CPF, CBPF and TPSCF results of TGM}

Conventional CPF, CBPF and TPSCF plots for TGM concentrations higher than the average concentration show high source probabilities to the west in the direction of large steel manufacturing facilities and waste incinerators (Fig. 4). The CPF only shows high probabilities from the west and 
provides no further information; however, the CBPF shows groups of sources with the high probabilities from the west and the northeast. CBPF shows that the high probabilities from the west occurred under high wind speed $\left(>3 \mathrm{~m} \mathrm{~s}^{-1}\right)$ indicative of emissions from stacks as well as low wind speed $\left(\leq 3 \mathrm{~m} \mathrm{~s}^{-1}\right)$ indicative of non-buoyant ground level sources (Uria-Tellaetxe and Carslaw, 2014).

As described in Sect. 5.3, correlations between TGM and $\mathrm{CO}$ revealed that TGM and $\mathrm{CO}$ were affected by similar anthropogenic emission sources in winter but affected by different sources in spring, summer and fall, which is supported by Fig. S6, which shows significantly different seasonal patterns of CPF and CBPF for TGM concentrations. However, compared to Fig. 4, the $\mathrm{CPF}$ and $\mathrm{CBPF}$ patterns in fall were similar to those during the whole sampling periods. In particular, the nighttime TGM concentration in fall was simultaneously positively correlated with $\mathrm{PM}_{10}(r=0.26, p<0.05)$ and $\mathrm{CO}(r=0.21, p<0.05)$ concentrations and wind speed $(r=0.35, p<0.01)$, indicating that the combustion process from the west is an important source during this period.

Since TGM showed a significant correlation with $\mathrm{CO}(r=$ $0.25, p<0.05$ ) and showed a weak positive correlation with $\mathrm{PM}_{10}(r=0.08, p=0.33)$ in winter with high wind speed, combustion sources from the west are likely partially responsible for this result.

TPSCF identified the likely sources of TGM as the iron and manufacturing facilities and the hazardous waste incinerators which are located to the west of the sampling site. A previous study reported that the waste incinerators $(9 \%)$ and iron and steel manufacturing (7\%) were relatively high $\mathrm{Hg}$ emissions sources in Korea (Kim et al., 2010). Waste incinerator emissions were due to the high $\mathrm{Hg}$ content in the waste (Lee et al., 2004). Emissions from iron and steel manufacturing are due to the numerous electric and sintering furnaces using coking, which emits relatively high mercury concentrations (Lee et al., 2004) in Gyeongsangbuk-do, including Pohang. There are several coke plants around the sampling site (http://www.poscoenc.com/upload/W/BUSINESS/PDF/ ENG_PLANT_2_1_3_5.pdf; last access: 9 December 015). They are essential parts of the iron and steel manufacturing, and the major source of atmospheric mercury related to the iron and steel manufacturing is from coke production ( $\mathrm{Pa}$ cyna et al., 2006).

The coastal areas east of the sampling site where there are large ports were also identified as the likely source areas of TGM. A previous study reported that the emissions of gaseous and particulate pollutants were high during vehicular operations in port areas and from marine vessel and launches (Gupta et al., 2002). Another possibility is that significant amount of GEM are emitted from the ocean surface because of photochemically and microbiologically mediated photoreduction of dissolved GOM (Amyot et al., 1994; Zhang and Lindberg, 2001). The northeast direction including the East Sea was also identified as potential source areas likely because this is an area with lots of domestic passenger ship routes. The area south of the sampling site was also identified as a likely source area of TGM where Ulsan metropolitan city, South Korea's seventh-largest metropolis with a population of over 1.1 million, is located. It includes a large petrochemical complex known as a TGM source (Jen et al., 2013).

\section{Conclusions}

During the sampling periods, the average TGM concentration was higher than the Northern Hemisphere background concentration, albeit considerably lower than those near urban areas in China and higher than those in Japan and other locations in Korea. The median concentration of TGM was much lower than that of the average, suggesting that there were some extreme pollution episodes with very high TGM concentrations. The TGM concentration was highest in fall, followed by spring, winter and summer. The high TGM concentration in fall is due to transport from different wind directions than during the other periods. The low TGM concentration in summer is likely due to increased mixing height and gas phase oxidation at higher temperatures particularly at this sampling site, which is close to the ocean $(2 \mathrm{~km})$, where oxidation involving halogens may be enhanced.

TGM consistently showed a diurnal variation with a maximum in the early morning (06:00-09:00) and minimum in the afternoon (14:00-17:00). Although there was a statistically significant negative correlation between the TGM concentration and ambient air temperature, the daytime TGM concentration was higher than those in the nighttime, suggesting that local emission sources are important. There was a negative relationship between the TGM concentrations and $\mathrm{O}_{3}$ concentrations, indicating that the oxidation was partially responsible for the diurnal variations of TGM concentrations. The observed $\Delta \mathrm{TGM} / \triangle \mathrm{CO}$ was significantly lower than that indicative of Asian long-range transport, suggesting that local sources are more important than those of long-range transport. CPF only shows high probabilities to the west of the sampling site where there are large steel manufacturing facilities and waste incinerators. However, CBPF and TPSCF indicated that the dominant sources of TGM were the hazardous waste incinerators and the coastal areas in the northeast as well as the iron and manufacturing facilities in the west. The domestic passenger ship routes in the East Sea were also identified as possible source areas.

\section{The Supplement related to this article is available online at doi:10.5194/acp-16-10215-2016-supplement.}

Author contributions. Yong-Seok Seo conducted a design of the study, the experiments and analysis of data; wrote the initial manuscript; and finally approved the final manuscript. Seung-Pyo 
Jeong, Eun Ha Park, Tae Young Kim, Hee-Sang Eum, Dae Gun Park, Eunhye Kim, Jaewon Choi and Jeong-Hun Kim conducted the experiments and analysis of data, and finally approved the final manuscript. Thomas M. Holsen, Young-Ji Han and Eunhwa Choi and Soontae Kim conducted interpretation of the results and revision of the initial manuscript, and finally approved the final manuscript. Seung-Muk Yi conducted a design of the study, acquisition of data of the study, interpretation of data and revision of the initial manuscript, and finally approved the final manuscript.

Acknowledgements. We thank the National Institute of Environmental Research (NIER) for providing CAPSS data.

This work was supported by the National Research Foundation of Korea (NRF) (NRF-2008-0059001), the Korean Ministry of Environment (MOE) as "the Environmental Health Action Program" (2015001370001) and the Brain Korea 21 (BK21) Plus Project (Center for Healthy Environment Education and Research) through the NRF.

Edited by: L. Zhang

Reviewed by: two anonymous referees

\section{References}

Adame, J., Notario, A., Villanueva, F., and Albaladejo, J.: Application of cluster analysis to surface ozone, $\mathrm{NO}_{2}$ and $\mathrm{SO}_{2}$ daily patterns in an industrial area in Central-Southern Spain measured with a DOAS system, Sci. Total Environ., 429, 281-291, 2012.

AMAP/UNEP: Technical Background Report for the Global Mercury Assessment 2013. Arctic Monitoring and Assessment Programme, Oslo, Norway/UNEP Chemicals Branch, Geneva, Switzerland, 263 pp., 2013.

Amyot, M., Mcqueen, D. J., Mierle, G., and Lean, D. R.: Sunlightinduced formation of dissolved gaseous mercury in lake waters, Environ. Sci. Technol., 28, 2366-2371, 1994.

Ashbaugh, L. L., Malm, W. C., and Sadeh, W. Z.: A residence time probability analysis of sulfur concentrations at Grand Canyon National Park, Atmos. Environ., 19, 1263-1270, 1985.

Begum, B. A., Kim, E., Biswas, S. K., and Hopke, P. K.: Investigation of sources of atmospheric aerosol at urban and semi-urban areas in Bangladesh, Atmos. Environ., 38, 3025-3038, 2004.

Brown, R. J., Goddard, S. L., Butterfield, D. M., Brown, A. S., Robins, C., Mustoe, C. L., and Mcghee, E. A.: Ten years of mercury measurement at urban and industrial air quality monitoring stations in the UK, Atmos. Environ., 109, 1-8, 2015.

Bullock, O. R., Brehme, K. A., and Mapp, G. R.: Lagrangian modeling of mercury air emission, transport and deposition: an analysis of model sensitivity to emissions uncertainty, Sci. Total Environ., 213, 1-12, 1998.

Chen, L., Liu, M., Xu, Z., Fan, R., Tao, J., Chen, D., Zhang, D., Xie, D., and Sun, J.: Variation trends and influencing factors of total gaseous mercury in the Pearl River Delta - A highly industrialised region in South China influenced by seasonal monsoons, Atmos. Environ., 77, 757-766, 2013.

Cheng, I., Zhang, L., Mao, H., Blanchard, P., Tordon, R., and Dalziel, J.: Seasonal and diurnal patterns of speciated atmo- spheric mercury at a coastal-rural and a coastal-urban site, Atmos. Environ., 82, 193-205, 2014.

Cheng, M. D., Hopke, P. K., and Zeng, Y.: A receptor-oriented methodology for determining source regions of particulate sulfate observed at Dorset, Ontario, J. Geophys. Res.-Atmos., 98, 16839-16849, 1993.

Choi, E.-M., Kim, S.-H., Holsen, T. M., and Yi, S.-M.: Total gaseous concentrations in mercury in Seoul, Korea: local sources compared to long-range transport from China and Japan, Environ. Pollut., 157, 816-822, 2009.

Choi, E.-M., Heo, J.-B., Hopke, P. K., Jin, B.-B., and Yi, S.-M.: Identification, apportionment, and photochemical reactivity of non-methane hydrocarbon sources in Busan, Korea, Water, Air, Soil Pollut., 215, 67-82, 2011.

Choi, H.-D., Huang, J., Mondal, S., and Holsen, T. M.: Variation in concentrations of three mercury $(\mathrm{Hg})$ forms at a rural and a suburban site in New York State, Sci. Total Environ., 448, 96106, 2013.

Dommergue, A., Ferrari, C. P., Planchon, F. A., and Boutron, C. F.: Influence of anthropogenic sources on total gaseous mercury variability in Grenoble suburban air (France), Sci. Total Environ., 297, 203-213, 2002.

Durnford, D., Dastoor, A., Figueras-Nieto, D., and Ryjkov, A.: Long range transport of mercury to the Arctic and across Canada, Atmos. Chem. Phys., 10, 6063-6086, doi:10.5194/acp-10-60632010, 2010.

Dvonch, J., Graney, J., Marsik, F., Keeler, G., and Stevens, R.: An investigation of source-receptor relationships for mercury in south Florida using event precipitation data, Sci. Total Environ., 213, 95-108, 1998.

Ebinghaus, R., Jennings, S., Kock, H., Derwent, R., Manning, A., and Spain, T.: Decreasing trends in total gaseous mercury observations in baseline air at Mace Head, Ireland from 1996 to 2009, Atmos. Environ., 45, 3475-3480, 2011.

Fang, F., Wang, Q., and Li, J.: Urban environmental mercury in Changchun, a metropolitan city in Northeastern China: source, cycle, and fate, Sci. Total Environ., 330, 159-170, 2004.

Feng, X., Shang, L., Wang, S., Tang, S., and Zheng, W.: Temporal variation of total gaseous mercury in the air of Guiyang, China, J. Geophys. Res.-Atmos., 109, D03303, doi:10.1029/2003JD004159, 2004.

Flanders, J., Turner, R., Morrison, T., Jensen, R., Pizzuto, J., Skalak, K., and Stahl, R.: Distribution, behavior, and transport of inorganic and methylmercury in a high gradient stream, Appl. Geochem., 25, 1756-1769, 2010.

Friedli, H. R., Arellano Jr., A. F., Geng, F., Cai, C., and Pan, L.: Measurements of atmospheric mercury in Shanghai during September 2009, Atmos. Chem. Phys., 11, 3781-3788, doi:10.5194/acp-11-3781-2011, 2011.

Friedli, H. R., Radke, L. F., Prescott, R., Li, P., Woo, J. H., and Carmichael, G. R.: Mercury in the atmosphere around Japan, Korea, and China as observed during the 2001 ACEAsia field campaign: Measurements, distributions, sources, and implications, J. Geophys. Res.-Atmos., 109, D19S25, doi:10.1029/2003JD004244, 2004.

Fu, X., Feng, X., Zhu, W., Wang, S., and Lu, J.: Total gaseous mercury concentrations in ambient air in the eastern slope of Mt. Gongga, South-Eastern fringe of the Tibetan plateau, China, Atmos. Environ., 42, 970-979, 2008. 
Fu, X. W., Feng, X., Dong, Z. Q., Yin, R. S., Wang, J. X., Yang, Z. R., and Zhang, H.: Atmospheric gaseous elemental mercury (GEM) concentrations and mercury depositions at a high-altitude mountain peak in south China, Atmos. Chem. Phys., 10, 24252437, doi:10.5194/acp-10-2425-2010, 2010.

Fu, X., Zhang, H., Lin, C.-J., Feng, X., Zhou, L., and Fang, S.: Correlation slopes of GEM/CO, GEM/CO 2 , and GEM/CH 4 and estimated mercury emissions in China, South Asia, the Indochinese Peninsula, and Central Asia derived from observations in northwestern and southwestern China, Atmos. Chem. Phys., 15, 1013-1028, doi:10.5194/acp-15-1013-2015, 2015.

Gabriel, M. C., Williamson, D. G., Brooks, S., and Lindberg, S.: Atmospheric speciation of mercury in two contrasting Southeastern US airsheds, Atmos. Environ., 39, 4947-4958, 2005.

Gauchard, P.-A., Ferrari, C. P., Dommergue, A., Poissant, L., Pilote, M., Guehenneux, G., Boutron, C. F., and Baussand, P.: Atmospheric particle evolution during a nighttime atmospheric mercury depletion event in sub-Arctic at Kuujjuarapik/Whapmagoostui, Quebec, Canada, Sci. Total Environ., 336, 215-224, 2005.

Gupta, A., Patil, R., and Gupta, S.: Emissions of gaseous and particulate pollutants in a port and harbour region in India, Environ. Monit. Assess., 80, 187-205, 2002.

Hall, C. B., Mao, H., Ye, Z., Talbot, R., Ding, A., Zhang, Y., Zhu, J., Wang, T., Lin, C.-J., and Fu, C.: Sources and Dynamic Processes Controlling Background and Peak Concentrations of TGM in Nanjing, China, Atmosphere, 5, 124-155, 2014.

Han, Y.-J., Holsen, T. M., Hopke, P. K., Cheong, J.-P., Kim, H., and Yi, S.-M.: Identification of source locations for atmospheric dry deposition of heavy metals during yellow-sand events in Seoul, Korea in 1998 using hybrid receptor models, Atmos. Environ., 38, 5353-5361, 2004.

Han, Y.-J., Holsen, T. M., Hopke, P. K., and Yi, S.-M.: Comparison between back-trajectory based modeling and Lagrangian backward dispersion modeling for locating sources of reactive gaseous mercury, Environ. Sci. Technol., 39, 1715-1723, 2005.

Han, Y.-J., Kim, J.-E., Kim, P.-R., Kim, W.-J., Yi, S.-M., Seo, Y.-S., and Kim, S.-H.: General trends of atmospheric mercury concentrations in urban and rural areas in Korea and characteristics of high-concentration events, Atmos. Environ., 94, 754-764, 2014.

Heo, J.-B., Hopke, P., and Yi, S.-M.: Source apportionment of $\mathrm{PM}_{2.5}$ in Seoul, Korea, Atmos. Chem. Phys., 9, 4957-4971, doi:10.5194/acp-9-4957-2009, 2009.

Holmes, C. D., Jacob, D. J., Mason, R. P., and Jaffe, D. A.: Sources and deposition of reactive gaseous mercury in the marine atmosphere, Atmos. Environ., 43, 2278-2285, 2009.

Hopke, P., Barrie, L., Li, S. M., Cheng, M. D., Li, C., and Xie, Y.: Possible sources and preferred pathways for biogenic and nonsea-salt sulfur for the high Arctic, J. Geophys. Res.-Atmos., 100, 16595-16603, 1995.

Hopke, P. K.: Recent developments in receptor modeling, J. Chemometrics, 17, 255-265, 2003.

Hopke, P. K., Zhou, L., and Poirot, R. L.: Reconciling trajectory ensemble receptor model results with emissions, Environ. Sci. Technol., 39, 7980-7983, 2005.

Hoyer, M., Burke, J., and Keeler, G.: Atmospheric sources, transport and deposition of mercury in Michigan: Two years of event precipitation, Water, Air, Soil Pollut., 80, 199-208, 1995.
Hsu, Y.-K., Holsen, T. M., and Hopke, P. K.: Comparison of hybrid receptor models to locate PCB sources in Chicago, Atmos. Environ., 37, 545-562, 2003.

Huang, J., Choi, H.-D., Hopke, P. K., and Holsen, T. M.: Ambient mercury sources in Rochester, NY: results from principle components analysis (PCA) of mercury monitoring network data, Environ. Sci. Technol., 44, 8441-8445, 2010.

Jaffe, D., Prestbo, E., Swartzendruber, P., Weiss-Penzias, P., Kato, S., Takami, A., Hatakeyama, S., and Kajii, Y.: Export of atmospheric mercury from Asia, Atmos. Environ., 39, 3029-3038, 2005.

Jen, Y.-H., Yuan, C.-S., Hung, C.-H., Ie, I.-R., and Tsai, C.-M.: Tempospatial variation and partition of atmospheric mercury during wet and dry seasons at sensitivity sites within a heavily polluted industrial city, Aerosol Air Qual. Res, 13, 13-23, 2013.

Keeler, G. and Barres, J.: Sampling and Analysis for Atmospheric Mercury, Center for Environmental Research Information, Cincinati, 1999.

Kellerhals, M., Beauchamp, S., Belzer, W., Blanchard, P., Froude, F., Harvey, B., Mcdonald, K., Pilote, M., Poissant, L., and Puckett, K.: Temporal and spatial variability of total gaseous mercury in Canada: results from the Canadian Atmospheric Mercury Measurement Network (CAMNet), Atmos. Environ., 37, 10031011, 2003.

Kim, E., Hopke, P. K., and Edgerton, E. S.: Source identification of Atlanta aerosol by positive matrix factorization, J. Air Waste Manage. Assoc., 53, 731-739, 2003a.

Kim, E., Larson, T. V., Hopke, P. K., Slaughter, C., Sheppard, L. E., and Claiborn, C.: Source identification of $\mathrm{PM}_{2.5}$ in an arid Northwest US City by positive matrix factorization, Atmos. Res., 66, 291-305, 2003b.

Kim, J.-H., Park, J.-M., Lee, S.-B., Pudasainee, D., and Seo, Y.-C.: Anthropogenic mercury emission inventory with emission factors and total emission in Korea, Atmos. Environ., 44, 2714 2721, 2010.

Kim, K.-H., Brown, R. J., Kwon, E., Kim, I.-S., and Sohn, J.-R.: Atmospheric mercury at an urban station in Korea across three decades, Atmos. Environ., 131, 124-132, 2016.

Kim, K.-H. and Kim, M.-Y.: The effects of anthropogenic sources on temporal distribution characteristics of total gaseous mercury in Korea, Atmos. Environ., 34, 3337-3347, 2000.

Kim, K.-H. and Kim, M.-Y.: Some insights into short-term variability of total gaseous mercury in urban air, Atmos. Environ., 35, 49-59, 2001.

Kim, S.-H., Han, Y.-J., Holsen, T. M., and Yi, S.-M.: Characteristics of atmospheric speciated mercury concentrations (TGM, Hg (II) and $\mathrm{Hg}(\mathrm{p})$ ) in Seoul, Korea, Atmos. Environ., 43, 3267-3274, 2009.

Kuo, T.-H., Chang, C.-F., Urba, A., and Kvietkus, K.: Atmospheric gaseous mercury in Northern Taiwan, Sci. Total Environ., 368, 10-18, 2006.

Lai, S.-O., Holsen, T. M., Hopke, P. K., and Liu, P.: Wet deposition of mercury at a New York state rural site: concentrations, fluxes, and source areas, Atmos. Environ., 41, 4337-4348, 2007.

Laurier, F. J., Mason, R. P., Whalin, L., and Kato, S.: Reactive gaseous mercury formation in the North Pacific Ocean's marine boundary layer: A potential role of halogen chemistry, J. Geophys. Res.-Atmos., 108, D174529, doi:10.1029/2003JD003625, 2003. 
Lee, D. S., Dollard, G. J., and Pepler, S.: Gas-phase mercury in the atmosphere of the United Kingdom, Atmos. Environ., 32, 855864, 1998.

Lee, S. J., Seo, Y.-C., Jurng, J., Hong, J.-H., Park, J.-W., Hyun, J. E., and Lee, T. G.: Mercury emissions from selected stationary combustion sources in Korea, Sci. Total Environ., 325, 155-161, 2004

Li, Z., Xia, C., Wang, X., Xiang, Y., and Xie, Z.: Total gaseous mercury in Pearl River Delta region, China during 2008 winter period, Atmos. Environ., 45, 834-838, 2011.

Lim, C.-J., Cheng, M.-D., and Schroeder, W. H.: Transport patterns and potential sources of total gaseous mercury measured in Canadian high Arctic in 1995, Atmos. Environ., 35, 1141-1154, 2001.

Lin, C.-J. and Pehkonen, S. O.: The chemistry of atmospheric mercury: a review, Atmos. Environ., 33, 2067-2079, 1999.

Lin, C.-J., Pongprueksa, P., Lindberg, S. E., Pehkonen, S. O., Byun, D., and Jang, C.: Scientific uncertainties in atmospheric mercury models I: Model science evaluation, Atmos. Environ., 40, 29112928, 2006.

Lindberg, S., Bullock, R., Ebinghaus, R., Engstrom, D., Feng, X., Fitzgerald, W., Pirrone, N., Prestbo, E., and Seigneur, C.: A synthesis of progress and uncertainties in attributing the sources of mercury in deposition, AMBIO, 36, 19-33, 2007.

Liu, N., Qiu, G., Landis, M. S., Feng, X., Fu, X., and Shang, L.: Atmospheric mercury species measured in Guiyang, Guizhou province, southwest China, Atmos. Res., 100, 93-102, 2011.

Lu, J. Y. and Schroeder, W. H.: Annual time-series of total filterable atmospheric mercury concentrations in the Arctic, Tellus B, 56, 213-222, 2004.

Lynam, M. M. and Keeler, G. J.: Source-receptor relationships for atmospheric mercury in urban Detroit, Michigan, Atmos. Environ., 40, 3144-3155, 2006.

Mao, H., Talbot, R., Sigler, J., Sive, B., and Hegarty, J.: Seasonal and diurnal variations of $\mathrm{Hg}$ over New England, Atmos. Chem. Phys., 8, 1403-1421, doi:10.5194/acp-8-1403-2008, 2008.

Marumoto, K., Hayashi, M., and Takami, A.: Atmospheric mercury concentrations at two sites in the Kyushu Islands, Japan, and evidence of long-range transport from East Asia, Atmos. Environ., $117,147-155,2015$.

Mason, R. P. and Sheu, G. R.: Role of the ocean in the global mercury cycle, Global Biogeochem. Cy., 16, 40-1-40-14, 2002.

Miller, C. L., Watson, D. B., Lester, B. P., Lowe, K. A., Pierce, E. M., and Liang, L.: Characterization of soils from an industrial complex contaminated with elemental mercury, Environ. Res., 125, 20-29, 2013.

Muntean, M., Janssens-Maenhout, G., Song, S., Selin, N. E., Olivier, J. G., Guizzardi, D., Maas, R., and Dentener, F.: Trend analysis from 1970 to 2008 and model evaluation of EDGARv4 global gridded anthropogenic mercury emissions, Sci. Total Environ., 494, 337-350, 2014.

Nakagawa, R.: Studies on the levels in atmospheric concentrations of mercury in Japan, Chemosphere, 31, 2669-2676, 1995.

Nier: National Air Pollutants Emission 2011 (in Korean), 2011.

Obrist, D., Tas, E., Peleg, M., Matveev, V., Faïn, X., Asaf, D., and Luria, M.: Bromine-induced oxidation of mercury in the midlatitude atmosphere, Nat. Geosci., 4, 22-26, 2011.

Osawa, T., Ueno, T., and Fu, F.: Sequential variation of atmospheric mercury in Tokai-mura, seaside area of east- ern central Japan, J. Geophys. Res.-Atmos., 112, D19107, doi:10.1029/2007JD008538, 2007.

Pacyna, E. G., Pacyna, J., Sundseth, K., Munthe, J., Kindbom, K., Wilson, S., Steenhuisen, F., and Maxson, P.: Global emission of mercury to the atmosphere from anthropogenic sources in 2005 and projections to 2020, Atmos. Environ., 44, 2487-2499, 2010.

Pacyna, E. G., Pacyna, J. M., Steenhuisen, F., and Wilson, S.: Global anthropogenic mercury emission inventory for 2000, Atmos. Environ., 40, 4048-4063, 2006.

Pacyna, J. M., Pacyna, E. G., Steenhuisen, F., and Wilson, S.: Mapping 1995 global anthropogenic emissions of mercury, Atmos Environ., 37, 109-117, 2003.

Pirrone, N., Cinnirella, S., Feng, X., Finkelman, R., Friedli, H., Leaner, J., Mason, R., Mukherjee, A., Stracher, G., and Streets, D.: Global mercury emissions to the atmosphere from anthropogenic and natural sources, Atmospheric Chemistry and Physics, 10, 5951-5964, doi:10.5194/acp-10-5951-2010, 2010.

Pirrone, N., Aas, W., Cinnirella, S., Ebinghaus, R., Hedgecock, I. M., Pacyna, J., Sprovieri, F., and Sunderland, E. M.: Toward the next generation of air quality monitoring: Mercury, Atmos. Environ., 80, 599-611, 2013.

Poissant, L.: Potential sources of atmospheric total gaseous mercury in the St. Lawrence River valley, Atmos. Environ., 33, 25372547, 1999.

Polissar, A. V., Hopke, P. K., and Harris, J. M.: Source regions for atmospheric aerosol measured at Barrow, Alaska, Environ. Sci. Technol., 35, 4214-4226, 2001.

Sakata, M. and Marumoto, K.: Formation of atmospheric particulate mercury in the Tokyo metropolitan area, Atmos. Environ., 36, 239-246, 2002.

Sakata, M. and Marumoto, K.: Wet and dry deposition fluxes of mercury in Japan, Atmos. Environ., 39, 3139-3146, 2005.

Schmolke, S. R., Schroeder, W., Kock, H., Schneeberger, D., Munthe, J., and Ebinghaus, R.: Simultaneous measurements of total gaseous mercury at four sites on a $800 \mathrm{~km}$ transect: spatial distribution and short-time variability of total gaseous mercury over central Europe, Atmos. Environ., 33, 1725-1733, 1999.

Schroeder, W. H. and Munthe, J.: Atmospheric mercury - an overview, Atmos. Environ., 32, 809-822, 1998.

Seo, Y.-S., Han, Y.-J., Choi, H.-D., Holsen, T. M., and Yi, S.-M.: Characteristics of total mercury (TM) wet deposition: scavenging of atmospheric mercury species, Atmos. Environ., 49, 69-76, 2012.

Seo, Y.-S., Han, Y.-J., Holsen, T. M., Choi, E., Zoh, K.-D., and Yi, S.-M.: Source identification of total mercury (TM) wet deposition using a Lagrangian particle dispersion model (LPDM), Atmos. Environ., 104, 102-111, 2015.

Shon, Z.-H., Kim, K.-H., Kim, M.-Y., and Lee, M.: Modeling study of reactive gaseous mercury in the urban air, Atmos. Environ., 39, 749-761, 2005.

Slemr, F., Brunke, E. G., Ebinghaus, R., Temme, C., Munthe, J., Wängberg, I., Schroeder, W., Steffen, A., and Berg, T.: Worldwide trend of atmospheric mercury since 1977, Geophys. Res. Lett., 30, 101516, doi:10.1029/2003GL016954, 2003.

Song, X., Cheng, I., and Lu, J.: Annual atmospheric mercury species in downtown Toronto, Canada, J. Environ. Monit., 11, 660-669, 2009.

Sprovieri, F., Pirrone, N., Ebinghaus, R., Kock, H., and Dommergue, A.: A review of worldwide atmospheric mercury measure- 
ments, Atmos. Chem. Phys., 10, 8245-8265, doi:10.5194/acp10-8245-2010, 2010.

Stamenkovic, J., Lyman, S., and Gustin, M. S.: Seasonal and diel variation of atmospheric mercury concentrations in the Reno (Nevada, USA) airshed, Atmos. Environ., 41, 6662-6672, 2007.

Stohl, A., Eckhardt, S., Forster, C., James, P., Spichtinger, N., and Seibert, P.: A replacement for simple back trajectory calculations in the interpretation of atmospheric trace substance measurements, Atmos. Environ., 36, 4635-4648, 2002.

Streets, D. G., Devane, M. K., Lu, Z., Bond, T. C., Sunderland, E. M., and Jacob, D. J.: All-time releases of mercury to the atmosphere from human activities, Environ. Sci. Technol., 45, 1048510491, 2011.

Strode, S. A., Jaeglé, L., Selin, N. E., Jacob, D. J., Park, R. J., Yantosca, R. M., Mason, R. P., and Slemr, F.: Air-sea exchange in the global mercury cycle, Global Biogeochem. Cy., 21, GB1017, doi:10.1029/2006GB002766, 2007.

Temme, C., Blanchard, P., Steffen, A., Banic, C., Beauchamp, S., Poissant, L., Tordon, R., and Wiens, B.: Trend, seasonal and multivariate analysis study of total gaseous mercury data from the Canadian atmospheric mercury measurement network (CAMNet), Atmos. Environ., 41, 5423-5441, 2007.

UNEP: Global mercury assessment, UNEP Chemicals, available at: http://www.unep.org/chemicalsandwaste/Portals/9/Mercury/ Documents/final-assessment-report-25nov02.pdf (last access: 9 December 2015), 2002.

UNEP: The global atmospheric mercury assessment: Sources, emissions and transport, available at: http://www.unep.org/ chemicalsandwaste/Portals/9/Mercury/Documents/Publications/ UNEP_GlobalAtmosphericMercuryAssessment_May2009.pdf (last access: 9 December 2015), 2008.

Uria-Tellaetxe, I. and Carslaw, D. C.: Conditional bivariate probability function for source identification, Environ. Model. Software, 59, 1-9, 2014.

Wan, Q., Feng, X., Lu, J., Zheng, W., Song, X., Han, S., and Xu, H.: Atmospheric mercury in Changbai Mountain area, northeastern China I. The seasonal distribution pattern of total gaseous mercury and its potential sources, Environ. Res., 109, 201-206, 2009.

Weigelt, A., Ebinghaus, R., Manning, A., Derwent, R., Simmonds, P., Spain, T., Jennings, S., and Slemr, F.: Analysis and interpretation of 18 years of mercury observations since 1996 at Mace Head, Ireland, Atmos. Environ., 100, 85-93, 2015.
Weiss-Penzias, P., Jaffe, D. A., Mcclintick, A., Prestbo, E. M., and Landis, M. S.: Gaseous elemental mercury in the marine boundary layer: Evidence for rapid removal in anthropogenic pollution, Environ. Sci. Technol., 37, 3755-3763, 2003.

Weiss-Penzias, P., Jaffe, D. A., Swartzendruber, P., Dennison, J. B., Chand, D., Hafner, W., and Prestbo, E.: Observations of Asian air pollution in the free troposphere at Mount Bachelor Observatory during the spring of 2004, J. Geophys. Res.-Atmos., 111, D10304, doi:10.1029/2005JD006522, 2006.

Weiss-Penzias, P., Jaffe, D., Swartzendruber, P., Hafner, W., Chand, D., and Prestbo, E.: Quantifying Asian and biomass burning sources of mercury using the $\mathrm{Hg} / \mathrm{CO}$ ratio in pollution plumes observed at the Mount Bachelor Observatory, Atmos. Environ., 41, 4366-4379, 2007.

Wilson, S., Munthe, J., Sundseth, K., Maxson, P., Kindbom, K., Pacyna, J., and Steenhuisen, F.: Updating Historical Global Inventories of Anthropogenic Mercury Emissions to Air, AMAP Technical Report No. 3, Arctic Monitoring and Assessment Programme (AMAP), 2010.

Xie, Y. and Berkowitz, C. M.: The use of positive matrix factorization with conditional probability functions in air quality studies: an application to hydrocarbon emissions in Houston, Texas, Atmos. Environ., 40, 3070-3091, 2006.

Zeng, Y. and Hopke, P.: A study of the sources of acid precipitation in Ontario, Canada, Atmos. Environ., 23, 1499-1509, 1989.

Zhang, H. and Lindberg, S. E.: Sunlight and iron (III)-induced photochemical production of dissolved gaseous mercury in freshwater, Environ. Sci. Technol., 35, 928-935, 2001.

Zhang, L., Wang, S., Wang, L., Wu, Y., Duan, L., Wu, Q., Wang, F., Yang, M., Yang, H., Hao, J., and Liu, X.: Updated emission inventories for speciated atmospheric mercury from anthropogenic sources in China, Environ. Sci. Technol., 49, 3185-3194, 2015.

Zhao, W., Hopke, P. K., and Karl, T.: Source identification of volatile organic compounds in Houston, Texas, Environ. Sci. Technol., 38, 1338-1347, 2004.

Zhou, L., Kim, E., Hopke, P. K., Stanier, C. O., and Pandis, S.: Advanced factor analysis on Pittsburgh particle size-distribution data special issue of aerosol science and technology on findings from the Fine Particulate Matter Supersites Program, Aerosol Sci. Technol., 38, 118-132, 2004. 